\title{
Mesoporous Silica Materials and Nanoparticles as Carriers for Controlled and Site-specific Delivery of Gaseous Signaling Molecules
}

\author{
Indranil Chakraborty and Pradip K. Mascharak* \\ Department of Chemistry and Biochemistry, University of California, Santa Cruz, CA \\ 95064, USA
}

e-mail: Pradip@ucsc.edu

Tel: +1 (831) 459-4251

FAX: +1 (831) 459-2935 


\begin{abstract}
Research during the past three decades has revealed that three small "toxic" molecules namely nitric oxide (NO), carbon monoxide $(\mathrm{CO})$ and hydrogen sulfide $\left(\mathrm{H}_{2} \mathrm{~S}\right)$ act as important signaling molecules in human physiology and pathology at submicromolar to micromolar levels. Modulations of the levels of these gasotransmitters at specific sites lead to various salutary effects. As a consequence, the quest for discrete and biocompatible molecules as well as delivery platforms that can deliver low doses of the three gasotransmitters under controlled conditions has gained significant momentum. The results of these attempts have now demonstrated that mesoporous silica materials (MSMs) and nanoparticles (MSNs) can serve as excellent carriers for pro-drug molecules and aid in site-specific delivery of the gasotransmitters under various stimuli such as $\mathrm{pH}$ change, temperature, and exposure to light. The review focuses on the development of such delivery systems and their biological applications.
\end{abstract}

\title{
Key Words
}

Mesoporous silica materials, gasotransmitters, CO and NO delivery, cancer cell eradication, antimicrobial agents 


\section{Introduction}

In recent years extraordinary research advances have been made to delineate the roles of three unusual signaling molecules namely, $\mathrm{NO}, \mathrm{CO}$, and $\mathrm{H}_{2} \mathrm{~S}$ in mammalian physiology and pathology [1-4]. Studies on the effects of nanomolar to micromolar levels of these three gaseous molecules on various biological targets have eventually led to a paradigm shift in the area of biological signal transduction and at present they belong to a new category of transmitters namely, the gasotransmitters ${ }^{3}$. Although these gases are usually considered as "toxic", all of them are produced endogenously through different mechanisms. For example, intracellular NO is produced by the enzymes NO synthases (NOSs), from arginine or anaerobically through nitrite reduction [5-7] while $\mathrm{CO}$ is generated endogenously by the enzyme heme oxygenases (HO) from the breakdown of heme[8]. Several mechanisms have been proposed for endogenous $\mathrm{H}_{2} \mathrm{~S}$ generation by enzymes cystathionine- $\beta$-synthase (CBS), cystathionine- $\gamma$-lyase (CSE), and 3mercaptopyruvate sulfur-transferase (MPST) [9]. These three gasotransmitters have been shown to participate in a myriad of biological processes including control of blood pressure, neurotransmission, inhibition of inflammation and infection, protection against oxidative damage, and restraint of tumor growth [4,10-16]. As a consequence, controlled delivery of small doses of these molecules can elicit salutary effects and such realization has opened up an entire new area of research on designed NO- and CO-donating drugs for various applications [17-21]. The impetus for syntheses of such NO and CO donors has primarily come from difficulties associated with applications of toxic gases (such as cumbersome gas delivery setups) under hospital settings. Most of the systemic NO 
donors such as glyceryl trinitrate (Fig. 1), diazeniumdiolates (NONOates), and Snitrosothiols afford NO upon exposure to heat, oxidants, $\mathrm{pH}$ changes and in some cases through enzymatic reactions [22-25]. Designed photoactive metal complexes with NO as ligands have also been shown to release NO under the control of light [26-29]. These NO-releasing molecules (NORMs) have been successfully used in delivering NO to malignant and infected sites [30-32]. The majority of CO-releasing molecules (CORMs, Fig. 1) are based on metal carbonyl complexes [33]. These metal-CO complexes undergo either solvent-assisted or photo-induced $\mathrm{CO}$ release and have been employed to deliver CO to biological targets [26, 34-40]. Despite success in animal models, CO donors await large-scale human trial and approval as drugs for pharmaceutical use at this time. Finally, research activity in the quest of exogenous compounds that promote slow release of $\mathrm{H}_{2} \mathrm{~S}[41,42]$ has afforded nonsteroidal anti-inflammatory drugs (such as $\mathrm{H}_{2} \mathrm{~S}$-releasing aspirin, Fig. 1) [43], caged gem-dithiol derivatives (releases $\mathrm{H}_{2} \mathrm{~S}$ upon illumination), [44] S-arylthioximes, and phosphinodithioates [45] as potential candidates for such purpose. Despite availability of several compounds with promising $\mathrm{H}_{2} \mathrm{~S}$-donating capability, $\mathrm{H}_{2} \mathrm{~S}$ donor development is still at an early stage [42].

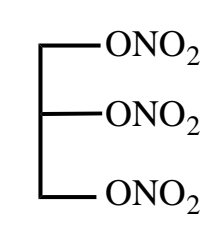

Glyceryl Trinitrate

NO donor

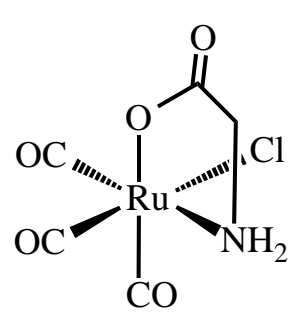

$\left[\mathrm{RuCl}(\right.$ glycinate $\left.)(\mathrm{CO})_{3}\right]$ CORM-3

CO donor

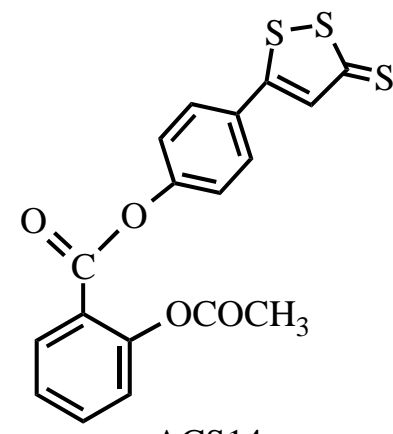

ACS14

$\mathrm{H}_{2} \mathrm{~S}$-releasing aspirin

$\mathrm{H}_{2} \mathrm{~S}$ donor 
Fig. 1. Examples of systemic drugs that release $\mathrm{NO}, \mathrm{CO}$ and $\mathrm{H}_{2} \mathrm{~S}$ respectively

\section{Challenges with delivery of gasotransmitters}

Multiple physiological effects of the gasotransmitters require precise delivery of these small diffusible molecules to their biological targets under controlled conditions to elicit specific salutary effects. Systemic donors such as glyceryl trinitrate (NO donor), CORM-3 ([Ru(glycinate) $\left.(\mathrm{CO})_{3} \mathrm{Cl}\right], \mathrm{CO}$-donor), and S-allyl cysteine $\left(\mathrm{H}_{2} \mathrm{~S}\right.$ donor $)$ all release the corresponding gasotransmitter in a steady fashion following their administration, a process that can be hardly controlled. The often $\mathrm{pH}-\mathrm{dependent}$ solventassisted release of the "drug" elsewhere in the body causes adverse side effects. This inexorability of gasotransmitter release becomes a major issue in many biomedical applications. During the past few years attempts have been made to design and isolate photoactive NO- and CO-donating molecules that can be triggered with lights of specific wavelengths to release $\mathrm{NO}$ or $\mathrm{CO}$ on demand $[26,34,35]$. Several of these molecules, based on "smart design" principles, are metal nitrosyls (NO complex) or carbonyls (CO complex) derived from designed auxiliary ligands [46-48]. These metal complexes release $\mathrm{NO}$ or $\mathrm{CO}$ when illuminated with low-power lights of specific wavelengths and allow one to have total control on the delivery of the two gasotransmitters. Lighttriggered $\mathrm{H}_{2} \mathrm{~S}$ release has also been reported [44] though examples of such donors are quite limited. The large number of photoactive $\mathrm{NO}$ and $\mathrm{CO}$ donors on the other hand clearly poise as potential photochemotherapeutics for delivery of the toxic twins (NO and CO) to biological targets $[20,26,33]$. 
The major obstacle in applying the photoactive metal nitrosyl and carbonyl complexes as therapeutics arises from lack of appropriate vehicle to deliver these prodrug molecules precisely to target sites without indiscriminant loss to the surrounding matrices. Ideally the delivery vehicle should be biocompatible, and upon $\mathrm{NO}$ or $\mathrm{CO}$ release, the corresponding photoproduct(s) should be retained within the host matrix. Entrapment/incorporation of the $\mathrm{NO}$ and $\mathrm{CO}$ donors within such carriers would therefore ensure minimal side effects both from the prodrug molecules and any photodegradation product(s) after the drug (NO or $\mathrm{CO}$ ) had been delivered. In this regard silica-based mesoporous nanoparticles (MSNs) and materials (MSMs) as host are ideal to entrap such metal carbonyl and nitrosyl complexes as guest species. Mesoporous silica materials are attractive as delivery vehicle because of their biocompatibility, minimal toxicity and amenability for diverse functionalization [49-51]. Their relatively large surface area, high pore volumes and well-ordered pore distribution allow the adsorption of desired drug molecules into their pores that can be released locally [52-54]. In addition, these MSNs are found to be very advantageous in terms of facile cellular uptake and cause only marginal alterations in cellular metabolism [55]. Thorough in vivo investigation on biocompatibility of MSNs reveals that at relatively low dosage, they are well tolerated in a number of mammalian cells $[56,57]$. Moreover, mesoporous silica materials (MSNs and MSMs) have been employed in designing stimuli responsive delivery systems where the encapsulated drugs could be released by means of various triggers such as temperature, $\mathrm{pH}$, redox, magnetic field, and light [51,58,59].

During the past few years, attempts have been made [60-65] to employ MSNs and MSMs as host matrices for the delivery of NO and CO to malignant or infected sites. The 
results of these studies now indicate that MSNs and MSMs could be excellent vehicles for the delivery of the two gasotransmitters. This review provides an overview of various designed NO- and CO-delivering mesoporous silica-based composite materials to highlight the utility of mesoporous silica materials as carriers of gasotransmitters. As described in the following sections, such materials have shown promise in eradication of antibiotic-resistant bacteria as well as human cancer cells. Finally a short report on similar systems releasing $\mathrm{H}_{2} \mathrm{~S}$ is also included.

\section{NO-releasing mesoporous silica materials for eradication of bacteria}

An unpaired electron in the $\pi^{*}$ orbital of NO makes it a reactive gaseous molecule. The reactions of NO with oxygen and superoxide produce various reactive nitrogen oxide species (RNOS) all of which cause DNA alteration, protein modification and lipid peroxidation $[1,17]$. Such reactivity confers a broad spectrum of antimicrobial capabilities to NO $[1,10]$. Because of the multiple mechanisms by which NO presents toxicity towards microbes, bacteria seldom exhibit resistance to exogenous NO. As a consequence, NO and NO-releasing materials have emerged as unconventional therapeutics in combating chronic and severe infections [66,67]. Although gaseous NO exerts strong antimicrobial effect, this form of NO delivery is often difficult to administer in controlled doses and in a sustainable fashion [68].

To date, two types of NO-releasing materials have been developed to deliver NO to infection. The first type includes (a) trapped $\mathrm{NO}(\mathrm{g})$ within the pores of silicate nanoparticles [64] (NPs) and (b) silica NPs with NO-releasing molecules (such as NONOates and S-nitroso-N-acetyl penicillamine) grafted on the surface $[69,70]$. The 
second type involves mesoporous silica materials (MSMs) or nanoparticles (MSNs) as the carrier with NO-releasing pro-drugs incorporated within the pores of the host.

The first example of porous aluminosilicate-based NO carrier came from the work of Morris and coworkers who employed transition metal-exchanged zeolite-A as the host for NO and demonstrated their antithrombotic properties [65]. Instead of pressureinduced adsorption of NO in the porous framework of zeolites, this group exploited stronger binding of $\mathrm{NO}$ at transition metal sites within the zeolite framework (Fig. 2) [71]. Binding of NO at Co sites gives rise to better loading (and entrapment) of NO in the zeolite host $(1.7 \mathrm{mmol} / \mathrm{g}$ of zeolite). The NO load is readily released upon exposure to moisture and results in a sustained level of NO diffusing out of the zeolite. Such NO release has been utilized in inhibition of platelet aggregation and adhesion of human platelets in vitro [65]. Another NO-storing Zn-exchanged X-type zeolite has been shown to liberate NO upon contact with aqueous environment [72]. This MSM-based NO donor exhibits powerful antibacterial properties against clinically relevant strains of bacteria including Pseudomonas aeruginosa, methicillin-resistant Staphylococcus aureus (MRSA) and Clostridium difficile. Narin and coworkers has demonstrated strong antibacterial properties of an NO-loaded natural zeolite [73]. In this work, the zeolite was first activated at $400^{\circ} \mathrm{C}$ to exclude water followed by loading of $\mathrm{NO}$ under a continuous flow of $20 \mathrm{~mL} / \mathrm{min}$. Rapid eradication of both Gram-positive (Bacillus subtilis) and Gram-negative (Escherichia coli) bacteria was observed when the bacterial loads were kept in contact with the NO-releasing zeolite. In a recent account, Zhu and coworkers have reported acid-induced NO release from moisture-saturated $\mathrm{NaA}, \mathrm{NaY}$ zeolites, and mesoporous NaZSM-5 with pre-adsorbed NO [74]. The rate of NO release 
from these NO-loaded zeolites depends on $\mathrm{pH}$ values, temperature, and the volume ratio of liquid to solid. NO donors of this type could inhibit bacterial damage to the gastric mucosal integrity.

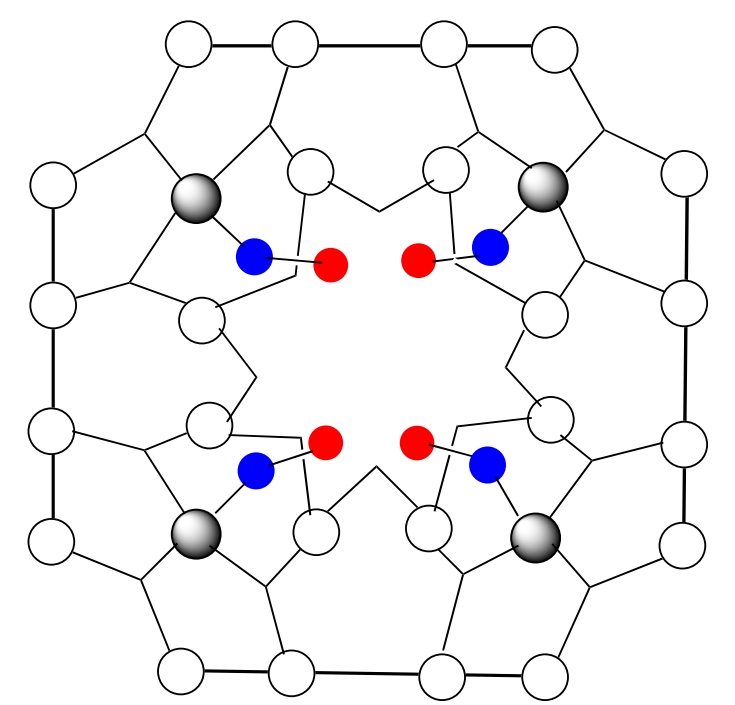

Fig. 2. Schematic representation of the cobalt-NO complex in zeolite-A (open circles $=\mathrm{Si}$ atoms; shaded circles $=\mathrm{Co}$ atoms; blue circles $=\mathrm{N}$ atoms;

red circles $=\mathrm{O}$ atoms $)$

The requirement of larger pore sizes for incorporation of NO-releasing molecules (invariably larger than NO) within the aluminosilicate framework has rapidly introduced MSMs and MSNs as carriers instead of zeolites. For example, Schoenfisch and coworkers have reported a new type of inorganic/organic hybrid MSNs that contain NONOates within the pores of the host framework [69]. The synthesis of these MSNs begins with the reaction of $\mathrm{N}$-(6-aminohexyl)aminopropyltrimethoxysilane (AHAP3) with high-pressure (6 atm) NO gas to isolate the corresponding NONOate AHAP3NO followed by methoxide-mediated hydrolysis of tetraethoxysilane (TEOS) and AHAP3NO in ethanol (Fig. 3B). The MSNs isolated in such protocol led to $40-45 \mathrm{~mol} \%$ 
NONOates and exhibits excellent NO release the rate of which depends on the particle size and composition. These MSNs exhibit strong bactericidal effect against $P$. aeruginosa, a common cause of burn wound infections [75]. Important is to note that the NONOate residues in these MSNs reside mostly on the surface of the composite particles. In latter attempts, this group has improved the extent of loading the NONOate moieties within the pores of the MSNs by following a different route [76]. The researchers first synthesized

A

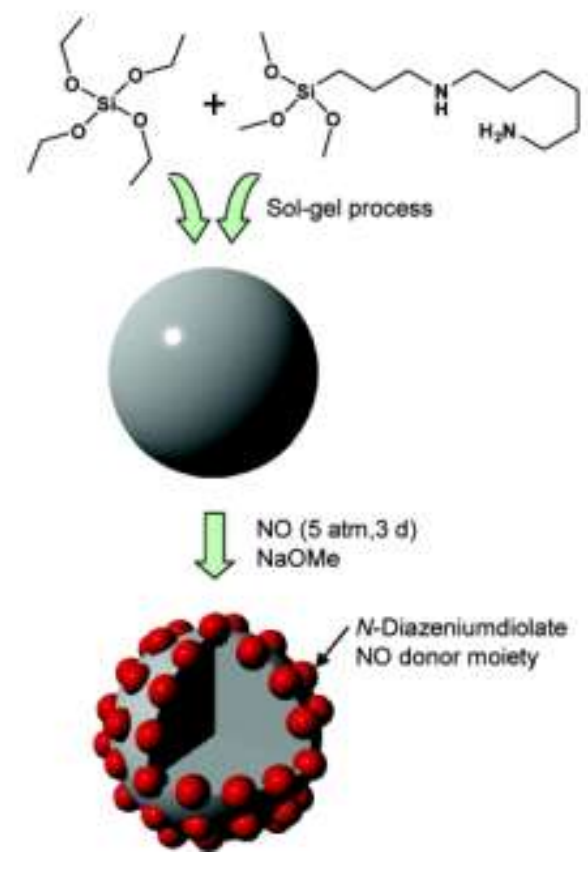

B

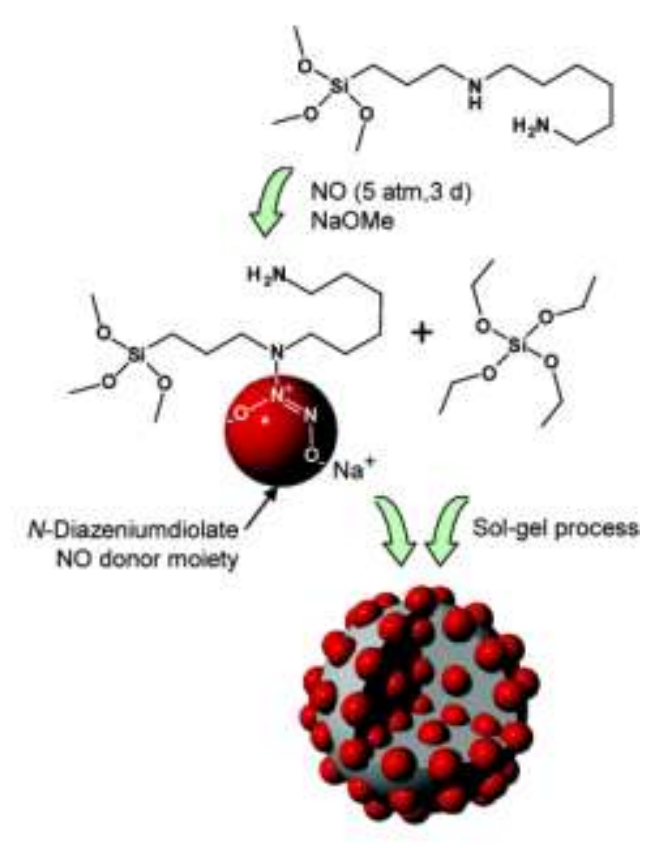

Fig. 3. Schematic description of the syntheses of NO-donating MSNs with NONOate moieties as the source of $\mathrm{NO}$ (adapted with permission from reference 69). Copyright 2008 American Chemical Society. The NO-donating MSMs can be constructed either first by isolating the MSNs with surface decorated with amino functionalities followed by nitrosation (Panel A) or first by isolating the NONOate of AHAP3 followed by MSN formation through sol-gel technique (Panel B). 
MSNs of different sizes through methoxide-mediated hydrolysis of TEOS in presence of cetyltriethylammonium bromide (CTAB). The MSNs thus generated was then reacted with different aminosilanes to remove $\mathrm{CTAB}$ from the pores via ion-exchange. The use of excess aminosilanes in this step allowed attachment of aminosilane moieties to the $\mathrm{Si}$ sites on the mesopore walls along with partial surface functionalization. High pressure NO reaction finally afforded the NONOate units within the pores of MSNs. An interesting use of these NO-releasing MSNs in coatings of subcutaneous implants to improve tissue biocompatibility (and avoid bio-fouling) has also been reported by Schoenfisch and coworkers [77]. This group has doped electrospun polyurethane fibers with the NO-releasing MSNs and demonstrated sustained (7h to 2 weeks) NO release from this macromolecular scaffold. The composite material shows excellent porosity with flexible plastic or elastomeric behavior.

Although the mesoporous zeolite-based NO-releasing materials mentioned above are highly biocompatible and function as excellent NO storage, acute susceptibility to water remains as an inherent limitation of this type of NO donors. In any biological application, the uncontrolled and rapid release of NO from such materials leads to loss of NO to non-targeted areas and side effects associated with such loss. Clearly, simple loading of NO gas within mesoporous framework does not afford control on the NO release from MSM or MSN-based materials. Such control requires further modification of the source of NO incorporated within the host matrix. Photoactive metal nitrosyl complexes in this regard are ideal candidates for more controlled and sustainable NO delivery because NO release from such donors can only be triggered by light of longer 
wavelengths (suitable for phototherapy). The photoproducts of these nitrosyl complexes often exert no side effects due to their entrapment within the mesoporous framework of the host following NO release.

Examples of light-triggered $\mathrm{NO}$ and $\mathrm{CO}$ release from the corresponding NORMs and CORMs entrapped within the pores of the mesoporous silica materials have come out of the research work of Mascharak and coworkers [60-62]. This group has been actively involved in synthesizing metal nitosyl complexes for controlled delivery of NO to biological targets [26,29]. Among several metal nitrosyls, the Fe [78,79] and Mn[80] complexes derived from the designed pentadentate ligand $\mathrm{PaPy}_{3} \mathrm{H}\left(\mathrm{PaPy}_{3} \mathrm{H}=N, N\right.$-bis(2pyridylmethyl)amine-N-ethyl-2-pyridine-2-carboxamide) are promising candidates due to their ability to rapidly release NO upon exposure to low power visible light (5-15 $\left.\mathrm{mW} / \mathrm{cm}^{2}\right)$. The manganese nitrosyl complex $[\mathrm{Mn}(\mathrm{PaPy})(\mathrm{NO})] \mathrm{ClO}_{4}(\{\mathrm{Mn}-\mathrm{NO}\}$ hereafter $)$ is particularly noteworthy for its solubility and stability in biological media (in absence of light). In addition, this NO donor can be easily incorporated in silicate-derived hydrogels and MSMs [81] For example powdered silica-based porous xerogels containing [MnNO\} has been incorporated in polyurethane films. This composite readily releases NO upon illumination with low power visible light and has been successfully applied to drastically reduce the bacterial load of both methicillin resistant S. aureus (MRSA) and Acenatobacter baumannii (a Gram-negative pathogen) [82]. A similar MSM with entrapped $\{\mathrm{Mn}-\mathrm{NO}\}$ has also been constructed for remote delivery of NO to infected targets through a catheter with built-in fiber-optic illumination system [32]. Rapid and effective eradication of both Gram-positive and Gram-negative bacteria ( $P$. aeruginosa, E. Coli, S. aureus and MRSA) under the total control of light has been achieved with this 
catheter. Schoenfisch and coworkers have utilized the photosensitivity of S-nitrosothiols (RSNOs) in 240-700 nm S-nitrosothiol-modified silica nanoparticles synthesized from co-condensation of mercaptopropyltrimethoxysilane and TEOS followed by nitrosation of the $-\mathrm{SH}$ groups with nitrous acid [83]. These MSNs release NO upon exposure to both heat and broadband white light. Because NO is a known inhibitor of platelet adhesion and smooth muscle cell proliferation, coatings of S-nitrosothiol-modified MSNs could be applied to intravascular sensors, extracorporeal blood loop circuits, and arteriovenous grafts/shunts to improve their thromboresistivity [67].

In their effort toward development of MSM-based NO-releasing material, Mascharak and coworkers have selected MCM-41 as the host for $\{\mathrm{Mn}-\mathrm{NO}\}$. The pore size of this mesoporous host is large enough to readily accommodate the positively charged $[\mathrm{Mn}(\mathrm{PaPy})(\mathrm{NO})]^{+}$units. Indeed, simple stirring of the zeolite with $\{\mathrm{Mn}-\mathrm{NO}\}$ in acetonitrile has afforded $\{\mathrm{Mn}-\mathrm{NO}\} @ \mathrm{MCM}-41$ as a pale green material that exhibits the spectral signature of the Mn complex thus confirming the integrity of the manganese complex [62]. Strong interaction of the polar nitrosyl with the hydroxyl groups on the surface of the pores leads to strong entrapment of the NO donor within the host structure. In order to increase the extent of loading of the cationic complex and improve retention of the NO donor within the host matrix, an aluminosilicate-based host material (AlMCM-41, 3 mol\% of Al) has also been used. The negatively-charged Al sites imparts even stronger electrostatic interactions with the cationic $[\mathrm{Mn}(\mathrm{PaPy})(\mathrm{NO})]^{+}$units entrapped within the pores of the host framework (confirmed by leaching experiments). Moreover, the dicationic photoproduct $\left[\mathrm{Mn}(\mathrm{PaPy})\left(\mathrm{H}_{2} \mathrm{O}\right)\right]^{2+}$ formed upon NO release is strongly retained within the host, a fact that ensures minimal or no side effects due any 
possible toxicity associated with the photoproduct. $\mathrm{N}_{2}$ adsorption studies and EDX elemental mapping of these materials indicate the presence of the manganese complex within the pores of the hosts. The powder X-ray diffraction (PXRD) pattern of the composite materials resemble closely with that of unloaded MCM-41 and Al-MCM-41 indicating that incorporation of the nitrosyl complex does not induce any major structural alteration within the MCM-41 framework. This finding has also been supported by transmission electron microscopy (TEM) analysis. These composite materials namely, $\{\mathrm{Mn}-\mathrm{NO}\} @ \mathrm{MCM}-41$ (with 5-10\% \{Mn-NO\} loading) and \{Mn-NO\}@Al-MCM-41 (with $15-25 \%$ \{Mn-NO $\}$ loading) demonstrate excellent antimicrobial activity towards multi drug resistant (MDR) A baumannii (Fig. 4) [62]. This pathogen has recently raised high levels of alarm in hospitals due to the occurrence of severe infections in soldiers returning from Operation Iraqi Freedom and Operation Enduring Freedom in Afghanistan. The NO releasing capacity of these MSM composites is quite notable. A sample of $10 \mathrm{mg}$ of $\{\mathrm{Mn}-\mathrm{NO}\} @ \mathrm{Al}-\mathrm{MCM}-41$ affords a steady release of $60-70 \mu \mathrm{M}$ concentrations of $\mathrm{NO}$ over a period of $60 \mathrm{~min}$.

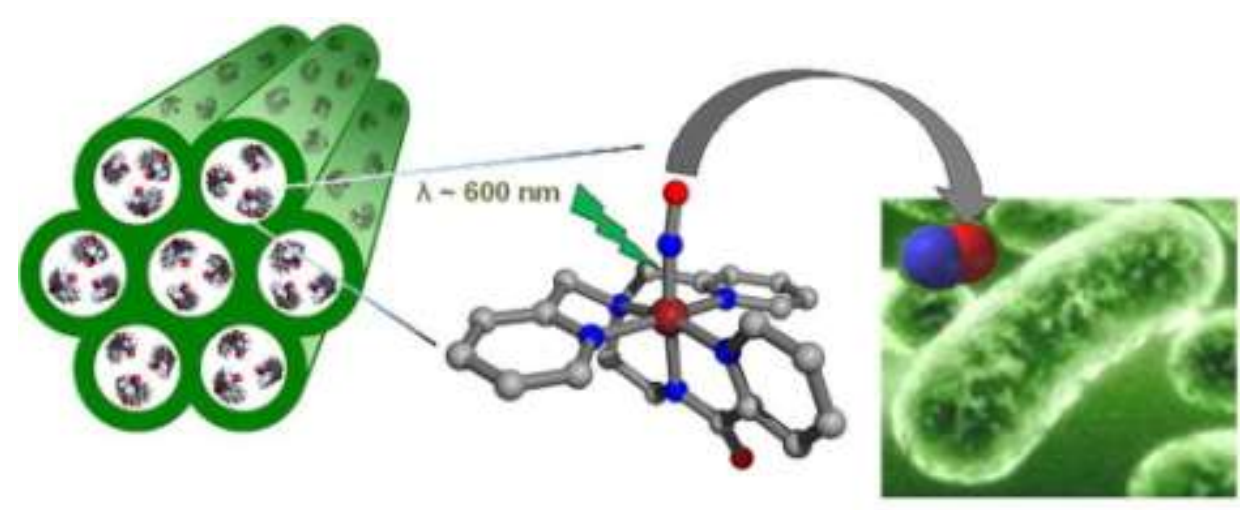

Fig. 4. Schematic representation of light-triggered NO delivery from 
\{Mn-NO\}@Al-MCM-41 to multidrug-resistant pathogen A. baumannii (adapted with permission from reference 62). Copyright 2012 American Chemical Society.

The therapeutic potential of $\{\mathrm{Mn}-\mathrm{NO}\} @ \mathrm{Al}-\mathrm{MCM}-41$ (a MSM-based NO donor) has been carefully assessed using a $1.5 \mathrm{~mm}$ thick skin and soft-tissue infection model (SSTI) loaded with the bacterial strains [62]. In these antimicrobial studies, application of $30 \mathrm{mg}$ and $50 \mathrm{mg}$ of $\{\mathrm{Mn}-\mathrm{NO}\} @ \mathrm{Al}-\mathrm{MCM}-41$ has resulted in sweeping reduction of the bacterial loads upon $1 \mathrm{~h}$ of visible light $\left(100 \mathrm{~mW} / \mathrm{cm}^{2}\right)$ illumination (Fig. 5). It is also important to note that control experiments with the photolyzed \{Mn-solv\}@Al-MCM-41 powder show no hindrance towards the growth of $A$. baummani. The most significant discovery of this study is the fact that complete clearing of the bacterial lawn of multi drug resistant $A$. baummani was achieved under similar conditions. The requirement of low power visible light for triggering the NO release is also a big advantage in practical application of such material. Simple spraying of the composite material on the infected wound and its exposure to sunlight could trigger the release of NO adequate for eradication of the pathogen. A final dressing of the wound would clear the NO-spent biocompatible powder from the wound site.

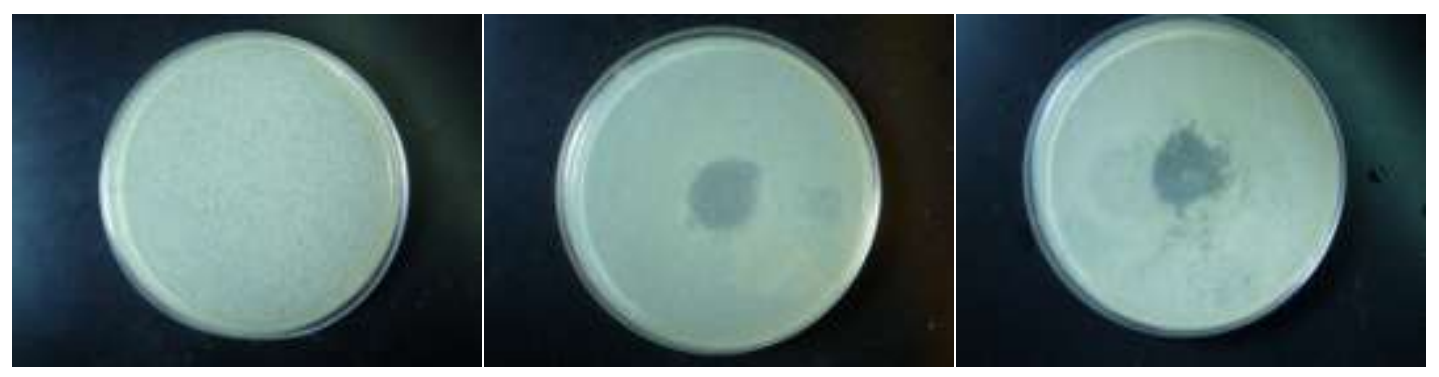

Fig. 5. Effects of NO photorelease from $\{\mathrm{Mn}-\mathrm{NO}\} @ \mathrm{Al}-\mathrm{MCM}-41$ on drugresistant $A$. baumannii colonies on a SSTI model (material sprayed on the central application zone). Left panel: Photoproduct showing no reduction of the bacterial load; 
center panel: clearing of bacterial load with 30 mg of $\{$ Mn-NO $\} @ A l-M C M-41$; right panel: clearing with 50 mg of $\{\mathrm{Mn}-\mathrm{NO}\} @ \mathrm{Al}-\mathrm{MCM}-41$.

The use of $\{$ Mn-NO $\}$ Al-MCM-41 has recently been extended to combat fungal infections. Candida albicans is a polymorphic fungus that can exist in yeast, pseudohyphal and hyphal form. The hyphal form is the invasive pathogen and can induce severe infections in immunocompromised patients (e.g. HIV patients, cancer patients and severe burn victims). Such invasion could lead to life-threatening conditions like candidiasis and sepsis. The effects of NO delivery to $C$. albicans infections have been closely examined by Mascharak and coworkers [84] Application of 10, 14 and $16 \mathrm{mg}$ of the evenly distributed composite material on SSTI models loaded with C. albicans followed by $1 \mathrm{~h}$ of illumination with visible light has resulted in eradication of the fungus in a dose-dependent manner. The antifungal effect of NO was limited to the place of application indicating "site-specific" NO-delivery. Also control experiment with the photolyzed solution of the composite material showed no antifungal activity suggesting that $\{$ Mn-solv $\} @ A l-M C M-41$ (the NO-spent material) itself is not effective in treating such infections. Interestingly, application of sub-lethal doses of NO from $\{\mathrm{Mn}-\mathrm{NO}\} @ \mathrm{Al}-$ MCM-41 on the yeast and hyphal form of $C$. albicans in separate experiments indicate that the hyphal form is more sensitive to NO compared to the yeast form. Collectively these results strongly suggest that light-triggered NO delivery by $\{\mathrm{Mn}-\mathrm{NO}\} @ \mathrm{Al}-\mathrm{MCM}-$ 41 could provide an excellent lenient means to treat $C$. albicans infections.

\section{Mesoporous silica materials with entrapped photoCORMs for CO delivery to biological targets}


Despite the notoriety as the "silent killer", $\mathrm{CO}$ in low doses exhibits a range of salutary effects. For example, CO provides potent cytoprotective effects in various organ and cell transplantations [85]. Exposure to low concentrations of $\mathrm{CO}$ also prevents ischemic reperfusion injury (IR) and relieves pulmonary hypertension [86]. These beneficial effects of $\mathrm{CO}$ can be conveniently achieved with the use of CORMs and photoCORMs that deliver the gasotransmittter in a much controlled manner [19,20,34]. In order to make $\mathrm{CO}$ delivery from these $\mathrm{CO}$ donors more site specific, attempts have been made to attach CORMs to various macromolecular carriers and inorganic scaffolds like polymers, silica nanoparticles, nanofibers, and metallodendrimers $[87,88]$. In selective cases, the composite materials exhibit salutary effects. For example a COreleasing PEG-based micelle carrier containing CORM-3 has been shown to attenuate lipopolysaccharide-induced NF- $\kappa$ B activation of human monocytes, [89] and CO delivery from a water-soluble styrene-maleic acid copolymer with encapsulated $\left[\mathrm{RuCl}_{2}(\mathrm{CO})_{3}\right]_{2}$ (CORM-2) has suppressed the dextransulfatesodium-induced colitis in mice [90]. However, examples of CO-delivery systems derived from MSMs and MSNs have been sparse so far.

At low concentrations (>200 ppm), CO promotes vasorelaxation much like its toxic twin NO $[2,13]$. Although CORMs have also been shown to elicit such response in animal studies, the first example of a MSN-based CO-donating composite that releases CO under controlled conditions to induce vasorelaxation was reported by Mascharak and coworkers in as late as 2014 [61]. This CO-delivery system consists of $60 \mathrm{~nm}$ Al-MCM41 MSNs packed with a photoactive manganese carbonyl complex namely $\left[\mathrm{Mn}(\mathrm{pqa})(\mathrm{CO})_{3}\right]_{\mathrm{ClO}_{4}} \quad(\{\mathrm{Mn}-\mathrm{CO}\} \quad$ hereafter; pqa $=$ (2-pyridylmethyl $)(2$-quinolyl- 
methyl)amine) (Fig. 6). Here again, the positively-charged $\left[\mathrm{Mn}(\mathrm{pqa})(\mathrm{CO})_{3}\right]^{+}$units are entrapped within the nanopores of the MSNs (Fig. 6) through strong electrostatic interactions at the negatively-charged $\mathrm{Al}$ sites as well as with the polar walls of the mesopores (confirmed by leaching experiment data). FTIR, PXRD, and TEM data of $\{\mathrm{Mn}-\mathrm{CO}\} @ \mathrm{Al}-\mathrm{MCM}-41$ all confirm the integrity of the complex upon encapsulation and the quasi-crystallinity of the host framework. The $\{\mathrm{Mn}-\mathrm{CO}\} @ \mathrm{Al}-\mathrm{MCM}-41$ composite (2 wt\% of $\mathrm{Mn}$ ) readily releases $\mathrm{CO}$ upon exposure to broad brand visible light (confirmed by myoglobin assay) and induces $\mathrm{CO}$-mediated vasorelaxation of pre-contracted rat aorta muscle rings. The CO-donating MSNs show excellent stability in biological media and
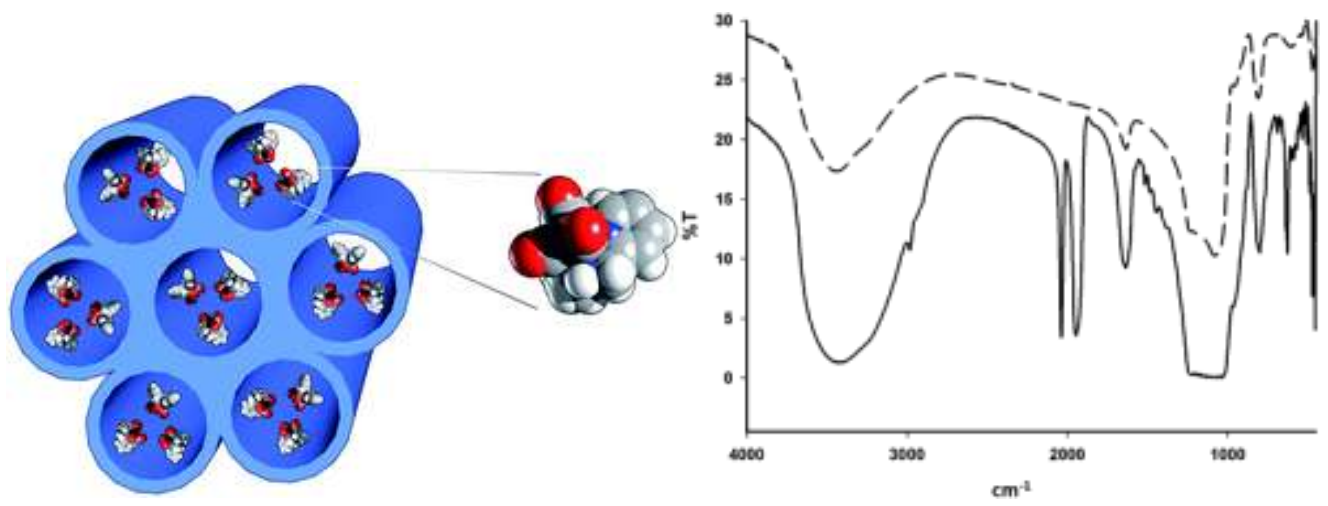

Fig. 6. Left panel: Schematic representation of $\{\mathrm{Mn}-\mathrm{CO}\} @ \mathrm{Al}-\mathrm{MCM}-41 \mathrm{MSN}$ showing entrapment of $\{\mathrm{Mn}-\mathrm{CO}\}$ (shown as a CPK model on right) within the pores of $70 \mathrm{~nm}$ Al-MCM-41 MSNs; right panel: FTIR spectra of empty Al-MCM-41 MSNs (dotted line) and $\{\mathrm{Mn}-\mathrm{CO}\} @ \mathrm{Al}-\mathrm{MCM}-41$ (solid line). The IR bands $\sim 2000 \mathrm{~cm}^{-1}$ correspond to the $\mathrm{CO}$ stretching modes of entrapped $\{\mathrm{Mn}-\mathrm{CO}\}$. (adapted with permission from reference 61). Copyright 2014 Royal Society of Chemistry.

provide moderate rates of $\mathrm{CO}$ release over extended periods under the total control of light. In this regard $\{\mathrm{Mn}-\mathrm{CO}\} @ \mathrm{Al}-\mathrm{MCM}-41$ is superior to the discrete photoCORM $\{\mathrm{Mn}-\mathrm{CO}\}$ as vasodilatory antihypertensive agent. In addition, retention of the 
photoproducts within the MSN host alleviates any complication arising from toxicity of any photoproduct.

In contrast to the strong anti-apoptotic and anti-inflammatory properties of $\mathrm{CO}$ at low concentrations (>200 ppm), a slightly higher concentration of CO can induce proapoptotic effects in cancer cells [19]. Results of both in vitro and in vivo experiments indicate that inducible heme oxygenase (HO-1) can impart anti-proliferative effect in breast and lung cancer cell lines [91]. Also, exposure to $\mathrm{CO}$ sensitizes prostate cancer cells (but not normal cells) to chemotherapy with growth arrest and apoptosis through metabolic exhaustion [92]. In general, when administered along with chemotherapeutics, $\mathrm{CO}$ increases the sensitivity to chemotherapy without affecting normal cells and tissues. It also prohibits angiogenesis and further metastasis of the cancer. During the past few years, CORMs and photoCORMs have shown promising capacity of eradication of different types of cancer cells [93-95]. For example, the photoCORM $\left[\mathrm{MnBr}(\mathrm{CO})_{3}(\right.$ azpy) $] \quad($ azpy $=2$-phenylazopyridine) exhibits rapid $\mathrm{CO}$ release upon illumination with low power $\left(10 \mathrm{~mW} / \mathrm{cm}^{2}\right)$ visible light and such $\mathrm{CO}$ release significantly reduces the cell viability of HeLa and MDA-MB-231 (human breast cancer) cells in a dose-dependent fashion [93]. In case of the photoCORM $\left[\operatorname{MnBr}(\mathrm{CO})_{3}(\mathrm{pbt})\right](\mathrm{pbt}=2-$ (pyridyl)benzo-thiazole), the light-induced $\mathrm{CO}$ release within cancer cells can be tracked through increase in fluorescence due to deligation of pbt (source of the fluorescence) following CO delivery [95]. Clearly the clinical utility of this type of CO donors could be extended to site-specific CO delivery through inclusion of these pro-drugs into suitable delivery vehicles. This proposition is particularly attractive in treatment of cancers that are otherwise resistant towards conventional chemotherapy. 
Mascharak and coworkers have recently employed $100 \mathrm{~nm}$ Al-MCM-41-based MSNs as the carrier for $\left[\mathrm{Re}\left(\mathrm{PPh}_{3}\right)(\mathrm{CO})_{3}(\mathrm{pbt})\right]\left(\mathrm{CF}_{3} \mathrm{SO}_{3}\right)$, a luminescent photoCORM ( $\{\mathrm{Re}-\mathrm{CO}\}$ hereafter), and examined the potential of $\{\mathrm{Re}-\mathrm{CO}\} @ \mathrm{Al}-\mathrm{MCM}-41$ in eradication of MDA-MB-231 cells in vitro [60]. The size of the carrier MSN was carefully chosen to ensure selective accumulation of the CO-donating material within cancer cells through the enhanced permeability and retention (EPR) effect [96-98]. The luminescent photoCORM $\{\mathrm{Re}-\mathrm{CO}\}$ was selected from a library of photoCORMs for visualization of

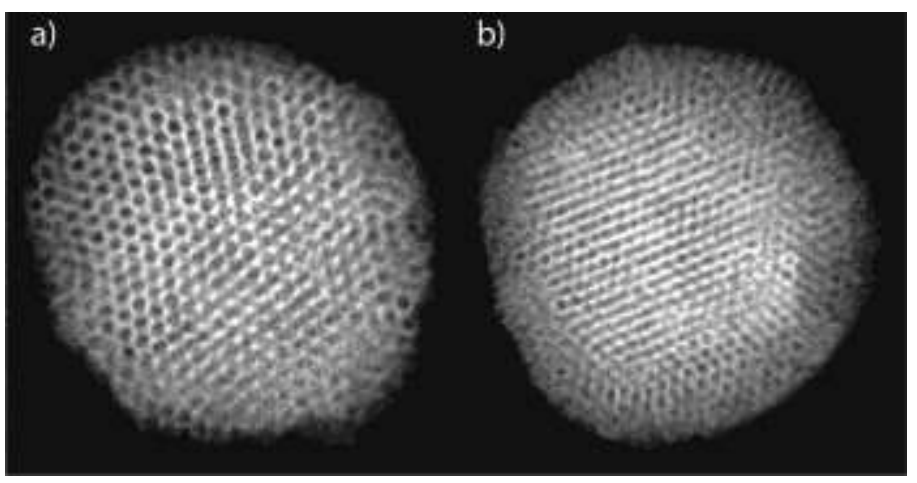

Fig. 7. TEM micrograph of (a) $100 \mathrm{~nm}$ Al-MCM-41 MSN and (b) $\{\mathrm{Re}-\mathrm{CO}\} @ \mathrm{Al}-\mathrm{MCM}-41$ (adapted with permission from reference 60). Copyright 2015 American Chemical Society.

the entry of the CO-donating material into the target cells. Collectively, the $\{\mathrm{Re}-$ CO\}@Al-MCM-41 MSNs (Fig. 7) represent a novel CO donor that allows tracking of the entire process of $\mathrm{CO}$ delivery, from the entry of the prodrug to the end of $\mathrm{CO}$ photorelease. For example, incubation of the luminescent $\{$ Re-CO $\} @ A l-M C M-41$ MSNs with MDA-MB-231 cells for $3 \mathrm{~h}$ in serum-free media allows entry of sufficient number of MSNs within the cancer cell. When such cells are washed and taken in PBS 
buffer with added Trypan blue (to quench any extra cellular fluorescence), they exhibit an orange fluorescence, readily observed by confocal microscopy, (Fig. 8) revealing effective internalization of the nanocomposite by the cancer cells [60]. Prior to this study, tracking of drug-loaded MSNs in cellular matrices required additional surface functionalization of the MSNs with fluorescent dyes such as fluorescein and rhodamine. The inherent luminescence of the prodrug $(\{\mathrm{Re}-\mathrm{CO}\})$ eliminates the necessity of organic dye molecules as reporters, which undoubtedly reduce the chances of any toxicity due to such compounds. The additional advantage of $\{\mathrm{Re}-\mathrm{CO}\} @ \mathrm{Al}-\mathrm{MCM}-41$ lies in the ease of tracking the event of $\mathrm{CO}$ release within the target cells through a real time "turn-off" luminescence event. Exposure of the MSN-loaded cells to low power UV light (305 nm, $5 \mathrm{~mW} / \mathrm{cm}^{2}$ ) leads to rapid loss of luminescence intensity due to conversion of the entrapped $\left[\operatorname{Re}\left(\mathrm{PPh}_{3}\right)(\mathrm{CO})_{3}(\mathrm{pbt})\right]^{+}$to non-fluorescent $\left[\operatorname{Re}\left(\mathrm{PPh}_{3}\right)(\mathrm{CO})_{2}(\mathrm{solv})(\mathrm{pbt})\right]^{+}$within the host framework (Fig. 8). Finally, the effects of $\mathrm{CO}$ on the viability of the cancer cells

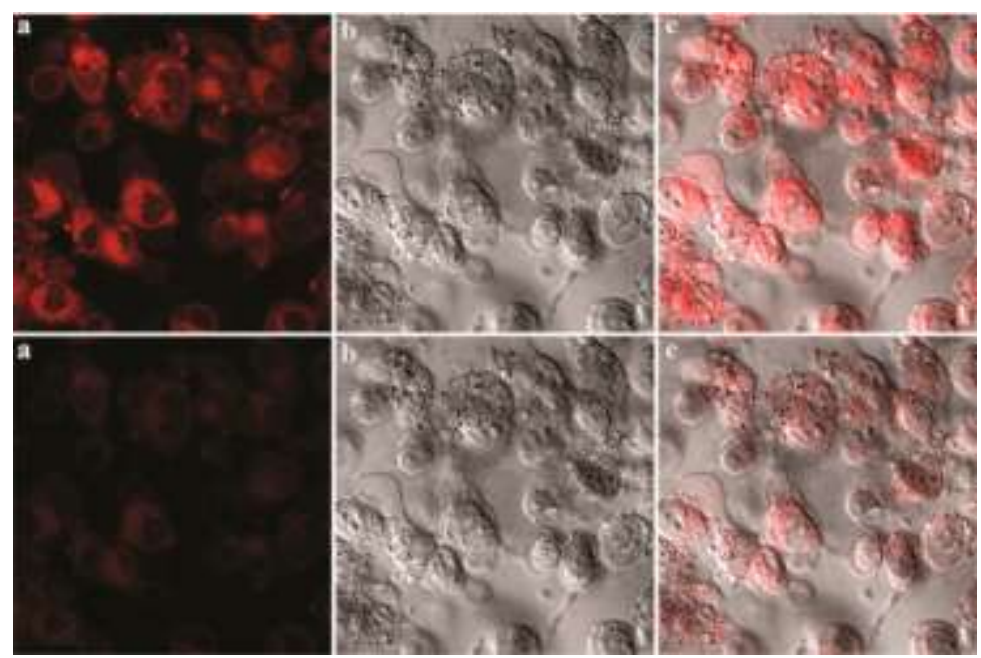

Fig. 8. Confocal microscopic images of MDA-MB-231 cancer cells after incubation with \{Re-CO\}@Al-MCM-41 for 3 h. Upper panel: (a) initial fluorescence image, (b) brightfield image, (c) merged image; lower panel: (a) fluorescence dimmed after 30 min of UV 
illumination, (b) the corresponding bright-field image, and (c) merged image. (adapted with permission from reference 60). Copyright 2015 American Chemical Society.

can be easily determined by MTT assay or FACS analysis. For example, in a typical experiment, treatment of MDA-MB-231 cells with $0.25 \mathrm{mg} / \mathrm{mL}$ of $\{\mathrm{Re}-\mathrm{CO}\} @ \mathrm{Al}-\mathrm{MCM}-$ 41 for $3 \mathrm{~h}$ and exposure to low power UV light for 15 min resulted in $80 \%$ decrease in cell viability as assessed by MTT assay. Taken together these results strongly suggest that incorporation of suitable photoCORM into MSNs could provide a novel CO delivery platform that would not only lead to eradication of cancer cells under controlled and sitespecific fashion but also allow one to track the $\mathrm{CO}$ delivery process through microscopic techniques.

\section{Mesoporous silica materials for $\mathrm{H}_{2} \mathrm{~S}$ delivery to biological targets}

Following the discovery of the potent cytoprotective actions of $\mathrm{H}_{2} \mathrm{~S}$, attempts have been made to employ exogenous $\mathrm{H}_{2} \mathrm{~S}$-releasing molecules to achieve strong cytoprotective actions of this gasotransmitter $[42,99]$. Unfortunately most of the known $\mathrm{H}_{2} \mathrm{~S}$-releasing molecules such as GYY4137 (a phosphinodithioate) and S-allyl cysteine (SAC) release $\mathrm{H}_{2} \mathrm{~S}$ in vivo at uncontrolled rates and hardly mimic the biological/endogenous $\mathrm{H}_{2} \mathrm{~S}$ generation. The fast and uncontrollable $\mathrm{H}_{2} \mathrm{~S}$ release can cause severe problems and sometimes can be even be lethal. Given the high activity of $\mathrm{H}_{2} \mathrm{~S}$, delivery of precise doses of this toxic gas thus requires suitably designed drug delivery systems. 


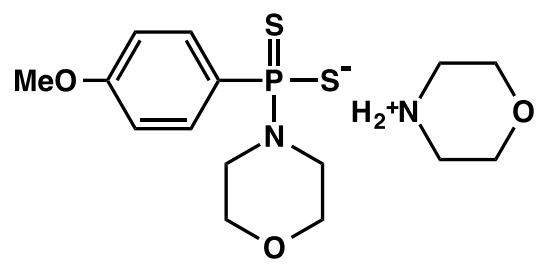

GYY4137

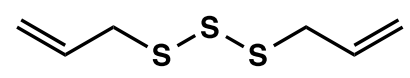

DATS

Fig 9. Examples of more commonly used $\mathrm{H}_{2} \mathrm{~S}$ donors

Mesoporous silica nanoparticles (MSNs) have recently been employed as carrier for $\mathrm{H}_{2} \mathrm{~S}$ donors to control their rates of $\mathrm{H}_{2} \mathrm{~S}$ release. Wang and coworkers have reported a $\mathrm{H}_{2} \mathrm{~S}$-delivery material consisting of $225 \mathrm{~nm}$ MSNs with diallyl trisulfide (DATS, a glutathione-triggered controlled release $\mathrm{H}_{2} \mathrm{~S}$ donor) packed within their pores [100]. The biocompatible DATS-MSN composite releases $\mathrm{H}_{2} \mathrm{~S}$ in PBS steadily the rate of which could be regulated by the glutathione concentration and $\mathrm{pH}$. Pretreatment of neonatal rat cardiomyocytes with such MSNs results in protection against hypoxia. When the DATScontaining MSNs are injected into the tail veins of male Sprague-Dawley rats, the in vivo $\mathrm{H}_{2} \mathrm{~S}$ release remains at a low and desired level in the blood plasma. This latter effect attests the potential of the composite material as $\mathrm{H}_{2} \mathrm{~S}$ donor that affords biologically relevant levels of $\mathrm{H}_{2} \mathrm{~S}$ in vivo. Additionally, encapsulation of DATS within the mesoporous framework improves the in vivo circulation time as well as the poor solubility of the $\mathrm{H}_{2} \mathrm{~S}$-releasing compound in aqueous media.

\section{Advantages and limitations of MSNs and MSMs as the delivery vehicles for NO, CO and $\mathrm{H}_{2} \mathrm{~S}$}

The discovery of the various roles of $\mathrm{NO}, \mathrm{CO}$ and $\mathrm{H}_{2} \mathrm{~S}$ as messengers of cellular signal transduction has stimulated the quest for discrete compounds as exogenous donors 
of these three gasotransmitters over the past several years. Because all three signaling molecules are very toxic and only very low and sustained levels elicit their physiological and pathological effects, control on the delivery is a crucial requirement in their applications. In addition, the delivery needs to be site specific to avoid side effects at undesired locations. Research to date has produced a plethora of organic compounds and metal complexes as pro-drugs that release these gasotransmitters (actual drugs) at various rates under different stimuli including $\mathrm{pH}$ change, enzymatic reactions, and light. Attempts to employ such compounds for site-specific delivery of the gasotransmitters have however revealed the necessity of biocompatible macromolecular scaffolds that will take the pro-drug to the target sites instead of a runaway distribution. To date, a wide variety of carriers including peptides, micelles, copolymers, fibers, mesoporous silica materials and nanoparticles (MSMs and MSNs), and metal-organic frameworks (MOFs) have been utilized as carriers of the three gasotransmitters (Table 1 and 2).

Table 1. Examples of delivery matrices for NO releasing molecules

$\begin{array}{lll}\text { Pro Drug molecule Host matrix } & \begin{array}{l}\text { Type of Composite } \\ \text { material }\end{array} & \text { References }\end{array}$

\begin{tabular}{llll}
\hline $\begin{array}{l}\text { S-nitrosothiol } \\
(\text { RSNO) }\end{array}$ & PEG-modified BSA & $\begin{array}{l}\text { NO releasing } \\
\text { proteins }\end{array}$ & [101] \\
$\mathrm{NO}(\mathrm{g})$ & $\begin{array}{l}\text { poly(vinyl alcohol) } \\
\text { (PVA) } \\
\text { microbubbles }\end{array}$ & $\begin{array}{l}\text { NO releasing } \\
\text { macromolecular } \\
\text { vesicles }\end{array}$ & \\
$\mathrm{NO}(\mathrm{g})$ & $\begin{array}{l}\text { Echogenic Liposomes } \\
\text { PROLI/NO }\end{array}$ & $\begin{array}{l}\text { Poly-lactic-co-glycolic } \\
\text { acid (PGLA) and }\end{array}$ &
\end{tabular}


polyethylene oxide-co-

lactic acid (PELA)

S-nitrosothiol

(RSNO)

$N$-diazeniumdiolate

Nitro nitroamide

$\mathrm{NO}(\mathrm{g})$

$\mathrm{NO}(\mathrm{g})$

$\mathrm{NO}(\mathrm{g})$

$N$-diazeniumdiolate

$N$-diazeniumdiolate

S-nitrosothiols

(RSNO)

$N$-diazeniumdiolate

S-nitrosothiol

(RSNO)

$N$-diazeniumdiolate

$N$-diazeniumdiolate

polyamidoamine

(PAMAM) dendrimers

gold nanoparticle

MPC

carboxy-terminated $\mathrm{Pt}$

nanoparticles

copper benzene

tricarboxylate metal

organic framework

material (HKUST-1)

Co-MOF and Ni-MOF

IRMOF-3 and UMCM-

1-NH2

fumed silica particles

fumed silica particles

amine-functionalized

silica nanoparticles

Thiol contatining Si

particles

Silica nanoparticles
NO releasing microparticles

Co-exchanged zeolite-A

NO releasing

Zeolites and

MOFs

[109]

[110]

[111]

NO releasing

silica particles

NO releasing

silica particles 


\begin{tabular}{|c|c|c|c|}
\hline$N$-diazeniumdiolate & $\begin{array}{l}\text { polyurethane and } \\
\text { poly(vinyl chloride) }\end{array}$ & & [116] \\
\hline $\mathrm{N}$-diazeniumdiolate & $\begin{array}{l}\text { Methyl methacrylate } \\
\text { based copolymers }\end{array}$ & $\begin{array}{l}\text { NO releasing } \\
\text { polymers }\end{array}$ & {$[117]$} \\
\hline N-diazeniumdiolate & $\begin{array}{l}\text { polypropylenimine } \\
\text { dendrimers }\end{array}$ & $\begin{array}{l}\text { NO releasing } \\
\text { dendrimers }\end{array}$ & [118] \\
\hline $\begin{array}{l}\text { S-nitrosothiol } \\
\text { (RSNO) }\end{array}$ & $\begin{array}{l}\text { polyamidoamine } \\
\text { (PAMAM) dendrimers }\end{array}$ & & [105] \\
\hline$N$-diazeniumdiolate & $\begin{array}{l}\text { aminosilanes and } \\
\text { alkylsilanes based sol- } \\
\text { gel matrix }\end{array}$ & & {$[119]$} \\
\hline$N$-diazeniumdiolate & $\begin{array}{l}\text { 3-trimethoxysilylpropyl) } \\
\text { diethylene- triamine } \\
\text { (DET3) and } \\
\text { isobutyltrimethoxysilane } \\
\text { (BTMOS) based sol-gel } \\
\text { matrix }\end{array}$ & $\begin{array}{l}\text { NO releasing sol- } \\
\text { gel material }\end{array}$ & {$[120]$} \\
\hline$N$-diazeniumdiolate & $\begin{array}{l}\text { silicon amino-alkoxide-- } \\
\text { based sol-gel }\end{array}$ & & {$[121]$} \\
\hline
\end{tabular}

Among these carriers, MSMs and MSNs are particularly noteworthy for their biocompatibility, low cost, ease of syntheses and functionalization, variable pore sizes, preferential accumulation at malignant sites due to EPR effects, and ability to retain the spent products leading to less side effects. Encapsulation of the pro-drugs into the pores of the carriers also raises the circulation time of the drug loads. Examples of MSMs and MSNs as delivery vehicles for the gasotransmitters highlighted in this mini-review clearly demonstrate that many pro-drugs can be taken to targeted sites and then be triggered to release the gasotransmitters at desired levels over a long period. Future 
efforts should be directed towards improvement of the target-specificity of the mesoporous carriers, their long-term stability, and safe exit from the biological system. Once these goals are achieved, the levels of the gasotransmitters at selected sites could be conveniently modulated through the use of designed pro-drugs entrapped within the pores of the mesoporous carriers and the biochemical roles of gasotransmitters could be further explored to broaden our understanding of the surprising salutary roles of these "toxic" molecules. Results from such pursuits could eventually lead to gasotransmitter-based therapeutics.

Mention must be made here about one challenge that remains as a major obstacle on the path towards this goal. Despite the promise of nanomedicine in the area of diagnosis and treatment of cancer, diabetes and several cardiovascular disorders, the extent of selective accumulation of the nanoparticle-drug composites within the target organ still has not reached their targeted range. In a very recent review article, Chan and coworkers have critically examined 224 manuscripts on nanoparticle-based drug delivery from past 10 years and reevaluated the results in detail [122]. Their analysis reveals that in all attempts so far, only $0.7 \%$ of the injected dose (ID) of any of the nanoparticulate drug/prodrug has reached the disease tissues (such as tumor sites) [122]. Nanoparticulate carriers injected into the body often encounter both physical and biological barriers that affect the percentage of drug/prodrug finally ending up into the diseased tissues and cells $[123,124]$. These barriers include diffusion flow and shear forces, self-aggregation, opsonin protein adsorption, phagocytic sequestration, and renal clearance. Although the EPR effect provides some help in accumulation of nanoparticulate drugs in tumors, this effect may not be uniform across all tumor types. For example, some tumor cells may 
possess leakier blood vessels and junctions than others. Therefore researchers need to find out other mechanism(s) of drug accumulation to the diseased tissues and focus on research to assess how the design of the nanoparticle hosts affects their capacity of tissue penetration and delivery efficiencies. New innovative design strategies are clearly required for nanocarriers with higher degree of accumulation at targeted sites. Close scrutiny of the reports published so far reveals that inorganic materials tend to provide higher delivery efficiency than those made from organic materials [122]. It is therefore reasonable to expect that porous silica-based nanoparticles will serve as superior delivery vehicles for the gasotransmitters as well as other small drug molecules.

Table 2. Examples of delivery matrices for $\mathrm{CO}$ releasing molecules Pro Drug molecules Host matrices Types of Composite materials

$\begin{aligned} {\left[\mathrm{Mn}(\mathrm{bpy})(\mathrm{CO})_{2}\left(\mathrm{PPh}_{3}\right)\right]^{+} \quad } & \text { amphiphilic } \\ & \text { phospholipid- } \\ & \text { funcyionalized } \\ & \text { PEG }\end{aligned}$

CORM-2

Styrene-maleic acid copolymer $\mathrm{CO}$ releasing (SMA)

Unsaturated cyclic $\alpha$ block copolymers diketones (DKs) of polyethylene oxide and polypropylene oxide (pluronic micelles)

CORM-3

PEG and micelles poly(butylacryl-

$\left[\operatorname{Re}(\mathrm{CO})_{3}\left(\mathrm{PPh}_{3}\right)(\mathrm{pbt})\right]^{+} \quad$ Al-MCM-41 


\begin{tabular}{|c|c|c|}
\hline & $(100 \mathrm{~nm})$ & $\begin{array}{l}\text { CO releasing } \\
\text { nanomaterials }\end{array}$ \\
\hline$\left[\mathrm{Mn}(\mathrm{CO})_{3}(\mathrm{pqa})\right]^{+}$ & $\begin{array}{l}\text { Al-MCM-41 (70 } \\
\mathrm{nm})\end{array}$ & \\
\hline $\begin{array}{l}\text { tri-(carbonyl)-chlorido- } \\
\text { phenylalaninato- } \\
\text { ruthenium(II) }\end{array}$ & $\begin{array}{l}\text { iron oxide } \\
\text { nanoparticles } \\
\text { (IONP) }\end{array}$ & \\
\hline CORM-2 & $\begin{array}{l}\mathrm{C}_{16} \mathrm{~V}_{3} \mathrm{~A}_{3} \mathrm{E}_{3} \mathrm{~K}(\mathrm{bD}) \\
\text { self assembling } \\
\text { peptide }\end{array}$ & $\begin{array}{l}\text { CO releasing } \\
\text { nanofiber gel }\end{array}$ \\
\hline $\begin{array}{l}{\left[\mathrm{Mn}\left(\mathrm{bpea}^{\mathrm{NHCH}} \underset{2}{\mathrm{C}}{ }_{4}^{\mathrm{H}} \mathrm{CHO}\right.\right.} \\
\left.(\mathrm{CO})_{3}\right]\end{array}$ & $\begin{array}{l}\text { peptides bearing } \\
\text { N-terminal alkyne, } \\
\text { azide, and aminoxy } \\
\text { residues }\end{array}$ & $\begin{array}{l}\text { CO releasing } \\
\text { peptide } \\
\text { conjugates }\end{array}$ \\
\hline$\left[\mathrm{Ru}(\mathrm{CO})_{2} \mathrm{Cl}_{2}\left(\right.\right.$ bpy $\left.\left.^{\text {substitued }}\right)\right]$ & PNA & \\
\hline$\left[\mathrm{Mo}(\mathrm{CO})_{4}\left(\mathrm{bpy}_{3}{ }^{\mathrm{CHO}}\right)\right]$ & $\begin{array}{l}\text { TGF) } \beta \text {-targeting } \\
\text { peptide } \mathrm{N} \text { - } \\
\text { terminally } \\
\text { functionalized with } \\
\text { aminoxy acetic } \\
\text { acid }\end{array}$ & \\
\hline$[\mathrm{Fe}(\mathrm{CO})(\mathrm{N} 4 \mathrm{Py})]\left(\mathrm{ClO}_{4}\right)_{2}$ & $\begin{array}{l}\text { Ac-Ala-Gly-OBn } \\
\text { peptide }\end{array}$ & \\
\hline CORM-2 & $\begin{array}{l}\text { hen egg white } \\
\text { lysozyme crystals } \\
\text { (CL-HEWLs) }\end{array}$ & $\begin{array}{l}\mathrm{CO} \text { releasing } \\
\text { protein }\end{array}$ \\
\hline$c i s-\left[\mathrm{Ru}(\mathrm{CO})_{2}\left(\mathrm{H}_{2} \mathrm{O}\right)_{4}\right]^{2+}$ & IL 8 & \\
\hline COMR-3 & HEWL protein & \\
\hline
\end{tabular}




$$
\begin{array}{lll}
{\left[\mathrm{Mn}(\mathrm{CO})_{3} \mathrm{I}(\mathrm{tacd})\right]^{+}} & \begin{array}{l}
\text { Cyanocobalamin } \\
\left(\mathrm{B}_{12}\right)
\end{array} & \begin{array}{l}
\mathrm{CO} \text { releasing } \\
\text { vitamin scaffold }
\end{array}
\end{array}
$$

$\left[\operatorname{Re}^{\mathrm{II}}(\mathrm{CO})_{2} \mathrm{Br}_{2}\right]$

Cyanocobalamin

$\left(\mathrm{B}_{12}\right)$

CORM-2

Galactopyranoside

CO releasing sugar molecules

$\left[\mathrm{MnBr}(\mathrm{CO})_{3}(\mathrm{bpy})\right]$

poly(propyleneimi

Dendritic CO ne-bipyridylimine) releasing materials dendrimers

CORM-2 block copolymers containing CO releasing polymeric poly(vinylpyridine) nanoparticles

CORM-2 cellulose coated Oral CO release $\mathrm{Na}_{2} \mathrm{SO}_{3}$ crystals system (OCORS)

\section{Acknowledgements}

Financial assistance from the NSF grants DMR-1409335 and CHE-0957251 is gratefully acknowledged.

\section{References}

[1] L. J. Ignarro, Ed., Nitric Oxide: Biology and Pathobiology. Academic Press, San Diego, (2000).

[2] R. Wang, Signal Transduction and the Gasotransmitters: NO, CO, and $\mathrm{H}_{2} \mathrm{~S}$ in Biology and Medicine, Humana Press, New Jersey, (2004). 
[3] A. Hermann, G. F. Sitdikova, T. M. Weiger, Eds., Gasotransmitters: Physiology and Pathophysiology, Springer, Heidelberg, (2012).

[4] P. K. Moore, M. Whiteman, Eds., Chemistry, Biochemistry and Pharmacology of Hydrogen Sulfide, Springer, Heidelberg, (2015).

[5] R. G. Knowles, S. Moncada, Biochem. J. 298 (1994) 249-258.

[6] M. A. Marletta, Cell 78 (1994) 927-930.

[7] J. O. Lundberg, E. Weitzberg, Arterioscler. Thromb. Vasc. Biol. 25 (2005) 915-922.

[8] G. Kikuchi, T. Yoshida, M. Noguchi, Biochem. Biophys. Res. Commun. 338 (2005) 558-567.

[9] M. M. Gadalla, S. H. Snyder, J. Neurochem. 113 (2010) 14-26.

[10] F. C. Fang, Ed., Nitric Oxide and Infection. Kluwer Academic/Plenum Publishers, New York, (1999).

[11] S. Kalsner, Ed., Nitric Oxide and Free radicals in Peripheral Neurotransmission. Birkhauser, Boston, (2000).

[12] S. Moncada, E. A. Higgs, G. Bagetta, Eds., Nitric Oxide and Cell Proliferation, Differentiation and Death. Portland Press, London, (1998).

[13] H. P. Kim, S. W. Ryter, A. M. K. Choi, Ann. Rev. Pharmacol. Toxicol. 46 (2006) 411-449.

[14] D. J. Kaczorowski, B. S. Zuckerbraun, Curr. Med. Chem. 14 (2007) 2720-2725.

[15] Q. Li, J. R. Lancaster, Jr. Nitric Oxide, 35 (2013) 21-34. 
[16] L. Li, P. Rose, P. K. Moore, Annu. Rev. Pharmacol. Toxicol. 51 (2011) 169-187.

[17] L. Ignarro, F. Murad, Nitric Oxide: Biochemistry, Molecular Biology, and Therapeutic Implications. Academic Press, (1995).

[18] Wang, P. G., Cai, T. B. and Taniguchi, N., Eds., Nitric Oxide Donors for Pharmaceutical and Biological Applications. Wiley-VCH, Weinheim, Germany, (2005).

[19] R. Motterlini, L. E. Otterbein, Nat. Rev. Drug. Discov. 9 (2010) 728-743.

[20] C. C. Romão, W. A. Blättler, J. D. Seixas, G. J. L. Bernardes, Chem. Soc. Rev. 41 (2012) 3571-3583.

[21] B. E. Mann, R. Motterlini, Chem. Comm. (2007) 4197-4208.

[22] C. S. Degoute, Drugs, 67 (2007) 1053-1076.

[23] H. H. Al-Sadoni, A. Ferro, Rev. Med. Chem. 5 (2005) 247-254.

[24] C. Napoli, L. J. Ignarro, Ann. Rev. Pharmacol. Toxicol. 43 (2003) 97-123.

[25] P. G. Wang, M. Xian, X. Tang, X. Wu, Z. Wen, T. Cai, A. J. Janczuk, Chem. Rev. 102 (2002) 1091-1134.

[26] B. J. Heilman, M. A. Gonzalez, P. K. Mascharak, Prog. Inorg. Chem. 58 (2014) 185224.

[27] P. K. Mascharak, Ind. J. Chem. A, 51A (2012) 99-107.

[28] M. J. Rose, P. K. Mascharak, Coord. Chem. Rev. 252 (2008) 2093-2114. 
[29] M. J. Rose, P. K. Mascharak, Curr. Opin. Chem. Biol. 12 (2008) 238-244.

[30] B. J. Heilman, P. K. Mascharak, Phil. Trans. R. Soc. 371 (2013) 2012.0368.

[31] M. J. Rose, N. L. Fry, R. Marlow, L. Hinck, P. K. Mascharak, J. Am. Chem. Soc. 130 (2008) 8834-8846.

[32] G. M. Halpenny, K. R. Gandhi, P. K. Mascharak, ACS Med. Chem. Lett. 1 (2010) 180-183.

[33] T. R. Johnson, B. E. Mann, J. E. Clark, R. Foresti, C. J. Green, R. Motterlini, Angew. Chem. Intl. Ed. 42 (2003) 3722-3729.

[34] S. Heinemann, T. Hoshi, M. Westerhausen, A. Schiller, Chem. Commun. 50 (2014) 3644-3660.

[35] M. A. Gonzalez, P. K. Mascharak, J. Inorg. Biochem. 133 (2014) 127-135.

[36] S. W. Ryter, A. M. K. Choi, Korean J. Intern. Med. 28 (2013) 123-140.

[37] U. Schatzschneider, Inorg. Chim. Acta 374 (201) 19-23.

[38] D. Crespy, K. Landfester, U. S. Schubert, A. Schiller, Chem. Commun. 46 (2010) 6651-6662.

[39] R. Alberto, R. Motterlini, Dalton Trans. (2007) 1651-1660.

[40] R. Motterlini, B. E. Mann, T. R. Johnson, J. E. Clark, R. Foresti, C. J. Green, Curr. Pharmaceu. Design. 9, (2003) 2525-2539. 
[41] K. Kashfi, K. R. Olson, Biochem. Pharmacol. 85 (2013) 689-703.

[42] Z. J. Song, M. Y. Ng, Z.-W. Lee, W. Dai, T. Hagen, P. K. Moore, D. Huang, L.-W. Deng, C.-H. Tan, MedChemComm, 5 (2014) 557-570.

[43] A. Sparatore, E. Perrino, V. Tazzari, D. Giustarini, R. Rossi, G. Rossoni, K. Erdman, H. Schröder, P. Del Soldato, Free Rad. Biol. Med. 46 (2009) 586-592.

[44] N. O. Devarie-Baez, P. E. Bagdon, B. Peng, Y. Zhao, C.-M. Park, M. Xian, Org. Lett. 15 (2013) 2786-2789.

[45] L. Li, M. Whiteman, Y. Y. Guan, K. L. Neo, Y. Cheng, S. W. Lee, Y. Zhao, R. Baskar, C.-H. Tan, P. K. Moore, Circulation, 117 (2008) 2351-2360.

[46] I. Chakraborty, S. J. Carrington, P. K. Mascharak, Acc. Chem. Res. 47 (2014) 26032611.

[47] N. L. Fry, P. K. Mascharak, Dalton Trans. 41 (2012) 4726-4735.

[48] N. L. Fry, P. K. Mascharak, Acc. Chem. Res. 44 (2011) 289-298.

[49] M. Colilla, B. Gonzalez, M. Vallet-Regi, Biomater. Sci. 1 (2013) 114-134.

[50] Z. Li, J. C. Barnes, A. Bosoy, J. F. Stoddart, J. I. Zink, Chem. Soc. Rev. 41 (2012) 2590-2605.

[51] M. Manzano, M. Vallet-Regi, J. Mater. Chem. 20 (2010) 5593-5604.

[52] V. Mamaeva, C. Sahlgren, M. Linden, Adv. Mater. Delivery Rev., 65 (2013) 689702. 
[53] I. Slowing, J. L. Vivero-Escoto, C. W. Wu, V. S. Y. Lin, Adv. Drug. Delivery Rev. 60 (2008) 1278-1288.

[54] Slowing, B. G. Trewyn, S. Giri, V. S. Y. Lin, Adv. Funct. Mater. 17 (2007) 12251236.

[55] S. Zhang, H. Gao, G. Bao, ACS Nano. 9 (2015) 8655-8671.

[56] Y. Zhao, X. Sun, G. Zhang, B. G. Trewyn, I. I. Slowing, V. S. Y. Lin, ACS Nano, 5 (2011) 1366-1375.

[57] J. Lu, M. Liong, Z. Li, J. I. Zink, F. Tamanoi, Small, 6 (2010) 1794-1805.

[58] M. W. Ambrogio, C. R. Thomas, Y.-L. Zhao, J. I. Zink, J. F. Stoddart, Acc. Chem. Res. 44 (2011) 903-913.

[59] E. Aznar, M. Oroval, L. Pascual, J. R. Murguia, R. M. Manez, F. Sancenon, Chem. Rev. 116 (2016) 561-718.

[60] I. Chakraborty, S. J. Carrington, J. Hauser, S. R. J. Oliver, P. K. Mascharak, Chem. Mater. 27 (2015) 8387-8397.

[61] M. Gonzalez, H Han, A. Moyes, A. Radinos, A. J. Hobbs, N. Coombs, S. R. J. Oliver, P. K. Mascharak, J. Mater. Chem. B, , 2 (2014) 2107-2113.

[62] B. J. Heilman, J. St. John, S. R. J. Oliver, P. K. Mascharak, J. Am. Chem. Soc. 134 (2012) 11573-11582.

[63] S. Fox, T. S. Wilkinson, P. S. Wheatley, B. Xiao, R. E. Morris, A. Sutherland, A. J. Simpson, P. G. Barlow, A. R. Butler, I. L. Megson, A. G. Rossi, Acta. Biomater. 6 (2010) $1515-1521$. 
[64] G. Han, L. R. Martinez, M. R. Mihu, A. J. Friedman, J. M. Friedman, J. S. Nosanchuk, PLoS ONE, 4 (2009) e7804.

[65] P. S. Wheatley, A. R. Butler, M. S. Crane, S. Fox, B. Xiao, A. G. Rossi, J. Am. Chem. Soc. 128 (2006) 502-509.

[66] G. M. Halpenny, P. K. Mascharak, Antiinfect. Agents Med. Chem. 9 (2010) 187197.

[67] M. C. Frost, M. M. Reynolds, M. E. Meyerhoff, Biomaterials. 26 (2005) 1685-1693.

[68] C. Miller, B. McMullin, A. Ghaffari, A. Stenzler, N. Pick, D. Roscoe, A. Ghahary, J. Road, Y. Av-Gay, Nitric Oxide. 20 (2009) 16-23.

[69] J. H. Shin, M. H. Schoenfisch, Chem. Mater. 20 (2008) 239-249.

[70] E. M. Hetrick, J. H. Shin, H. S. Paul, M. H. Schoenfisch, Biomaterials. 30 (2009) 2782-2789.

[71] W. A. Cruz, P. C. W. Leung, K. Seff, Inorg. Chem. 18 (1979) 1692-1696.

[72] S. Fox, T. S. Wilkinson, P. S. Wheatley, B. Xiao, R. E. Morris, A. Sutherland, A. J. Simpson, P. G. Barlow, A. R. Butler, I. L. Megson, A. G. Rossi, Acta. Biomater. 6 (2010) 1515-1521.

[73] G. Narin, C. B. Albayrak, S. Ülkü, Appl. Clay Sci. 50 (2010) 560-568.

[74] F. Wei, J. Y. Yang, Q. Hou, J. H. Zhu, New J. Chem. 34 (2010) 2897-2905. 
[75] E. M. Hetrick, J. H. Shin, N. A. Stasko, C. B. Johnson, D. A. Wespe, E. Holmuhamedov, M. H. Schoenfisch, ACS Nano. 2 (2008) 235-246.

[76] R. J. Soto, L. Yang, M. H. Schoenfisch, ACS Appl. Mater. Interfaces. 8 (2016) 2220-2231.

[77] A. Koh, A. W. Carpenter, D. L. Slomberg, M. H. Schoenfisch, ACS Appl. Mater. Interfaces. 5 (2013) 7956-7964.

[78] A. K. Patra, J. M. Rowland, D. S. Marlin, E. Bill, M. M. Olmstead, P. K. Mascharak, Inorg. Chem. 42 (2003) 6812-6823.

[79] A. K. Patra, R. K. Afshar, M. M. Olmstead, P. K. Mascharak, Angew. Chem. Int. Ed., 41 (2002) 2512-2515.

[80] K. Ghosh, A. A. Eroy-Reveles, B. Avila, T. R. Holman, M. M. Olmstead, P. K. Mascharak, Inorg. Chem. 43 (2004) 2988-2997.

[81] A. A. Eroy-Reveles, Y. Leung, C. M. Beavers, M. M. Olmstead, P. K. Mascharak, J. Am. Chem. Soc. 130 (2008) 4447-4458.

[82] B. J. Heilman, G. M. Halpenny, P. K. Mascharak, J. Biomed. Mater. Res. Part B Appl. Biomater. 99B (2011) 328-337.

[83] D. A. Riccio, J. L. Nugent, M. H. Schoenfisch, Chem. Mater. 23 (2011) 1727-1735.

[84] B. J. Heilman, A. C. Talde, L. R. Pimentel, P. K. Mascharak, J. Inorg. Biochem. 123 (2013) 18-22.

[85] A. Nakao, A. M. K. Choi, N. Murase, J. Cell. Mol. Med. 10 (2006) 650-671. 
[86] D. J. Kaczorowski, B. S. Zuckerbraun, Curr. Med. Chem. 14 (2007) 2720-2725.

[87] D. Nguyen, C. Boyer, ACS Biomater. Sci. Eng. 1 (2015) 895-913.

[88] H. Inaba, K. Fujita, T. Ueno, Biomater. Sci. 3 (2015) 1423-1438.

[89] U. Hasegawa, A. J. van der Vlies, E. Simeoni, C. Wandrey, J. A. Hubbell, J. Am. Chem. Soc. 132 (2010) 18273-18280.

[90] H. Yin, J. Fang, L. Liao, H. Nakamura, H. Maeda, J. Controlled Release. 187 (2014) $14-21$.

[91] B. Wegiel, B. Y. Chin, L. E. Otterbin, Cell Cycle 7 (2008)1379-1384.

[92] B. Wegiel, D. Gallo, E. Csizmadia, C. Harris, J. Belcher, G. M. Vercellotti, N. Penacho, P. Seth, V. Sukhatme, A. Ahmed, P. P. Pandolfi, L. Helczynski, A. Bjartell, J. L. Persson, L. E. Otterbein, Cancer. Res. 73 (2013) 7009-7021.

[93] S. J. Carrington, I. Chakraborty, P. K. Mascharak, Chem.Commun. 49 (2013) 11254-11256.

[94] J. Niesel, A. Pinto, H. W. P. N’Dongo, K. Merz, I. Ott, R.Gust, U. Schatzschneider, Chem. Commun. (2008) 1798-1800.

[95] S. J. Carrington, I. Chakraborty, J. M. L. Bernerd, P. K. Mascharak, ACS Med. Chem. Lett. 5 (2014) 1324-1328.

[96] K. Greish, Enhanced Permeability and Retention (EPR) Effect for Anticancer Nanomedicine Drug Targeting, Humana Press: New York (2010).

[97] H. Maeda, Adv. Enzyme Regul. 41 (2001) 189-207. 
[98] T. Sun, Y. S. Zhang, B. Pang, D. C. Hyun, M. Yang, Y. Xia, Angew. Chem. Int. Ed. 53 (2014) 12320-12364.

[99] Y. Zhao, T. D. Biggs, M. Xian, Chem. Commun. 50 (2014) 11788-11805.

[100] X. Sun, B. Kong, W. Wang, P. Chandran, C. Selomulya, H. Zhang, K. Zhu, Y. Liu, W. Yang, C. Guo, D. Zhao, C. Wang, J. Mater. Chem. B. 3 (2015) 4451-4457.

[101] H. Katsumi, M. Nishikawa, F. Yamashita, M. Hashida, J. Pharmacol. Exp. Ther., 314 (2005) 1117-1124.

[102] F. Cavalieri, I. Finelli, M. Tortora, P. Mozetic, E. Chiessi, F. Polizio, T. B.

Brismar, G. Paradossi, Chem. Mater., 20 (2008) 3254-3258.

[103] S. L. Huang, P. H. Kee, H. Kim, M. R. Moody, S. M. Chrzanowski, R. C. MacDonald, D. D. McPherson, J. Am. Coll. Cardiol., 54 (2009) 652-659.

[104] H. S. Jeh, S. Lu, S. C. George, J.Microencapsulation 21 (2004) 3-13

[105] N. A. Stasko, T. H. Fischer, M. H. Schoenfisch, Biomacromolecules, 9 (2008) 834-841.

[106] M. A. Polizzi, N. A. Stasko, M. H. Schoenfisch, Langmuir, 23 (2007) 4938-4943.

[107] E. B. Caruso, S. Petralia, S. Conoci, S. Giuffrida, S. Sortino, J. Am. Chem. Soc., 129 (2007) 480-481. 
[108] B. Xiao, P. S. Wheatley, X. Zhao, A. J. Fletcher, S. Fox, A. G. Rossi, I. L. Megson, S. Bordiga, L. Regli, K. M. Thomas, R. E. Morris, J. Am. Chem. Soc., 129 (2007) 12031209.

[109] A. C. McKinlay, B. Xiao, D. S. Wragg, P. S. Wheatley, I. L. Megson, R. E. Morris, J. Am. Chem. Soc., 130 (2008) 10440-10444.

[110] J. G. Nguyen, K. K. Tanabe, S. M. Cohen, CrystEngComm, 12 (2010) 2335-2338.

[111] H. Zhang, G. M. Annich, J. Miskulin, K. Stankiewicz, K. Osterholzer, S. I. Merz, R. H. Barlett, M. E. Meyerhoff, J. Am. Chem. Soc., 125 (2003) 5015-5024.

[112] M. C. Frost, M. E. Meyerhoff, J. Biomed. Res., Part A 72A (2005) 409-419.

[113] J. H. Shin, S. K. Metzger, M. E. Schoenfisch, J. Am. Chem. Soc., 129 (2007) 46124619.

[114] A. W. Carpenter, D. L. Slomberg, K. S. Rao, M. H. Schoenfisch, ACS Nano, 5 (2011) 7235-7244.

[115] D. J. Smith, D. Chakravarthy, S. Pulfer, M. L. Simmons, J. A. Hrabie, M. L. Citro, J. E. Saavedra, K. M. Davies, T. C. Hutsell, D. L. Mooradian, S. R. Hanson, L. K. Keefer, J. Med. Chem., 39 (1996) 1148-1156. 
[116] K. A. Mowery, M. H. Schoenfisch, J. E. Saavedra, L. K. Keefer, M. E. Meyerhoff, Biomaterials, 21 (2000) 9-21.

[117] P. G. Parzuchowski, M. C. Frost, M. E. Meyerhoff, J. Am. Chem. Soc., 124 (2002) 12182-12191.

[118] N. A. Stasko, M. H. Schoenfisch, J. Am. Chem. Soc., 128 (2006) 8265-8271.

[119] S. M. Marxer, A. R. Rothrock, B. J. Nablo, M. E. Robbins, M. H. Schoenfisch, Chem. Mater., 15 (2003) 4193-4199.

[120] B. J. Nablo, T. Y. Chen, M. H. Schoenfisch, J. Am. Chem. Soc., 123 (2001) 97129713.

[121] B. J. Nablo, M. H. Schoenfisch, J. Biomed. Mater. Res., 67A (2003) 1276-1283.

[122] S. Willhelm, A. J. Tavares, Q. Dai, S. Ihta, J. Audet, H. F. Dvorak, W. C. W. Chan, Nature Reviews Materials, (2016) doi:10.1038/natrevmats.2016.14.

[123] J. Lazarovtis, Y. Y. Chen, E. A. Sykes, W. C. W. Chan, Chem. Commun, 51 (2015) 2756-2767.

[124] A. T. Florence, J. Control. Release, 164 (2012) 115-124. 
[125] A. E. Pierri, P. J. Huang, J. V. Garcia, J. G. Stanfill, M. Chui, G. Wu, N. Zheng, P. C. Ford, Chem. Commun, 51 (2015) 2072-2075.

[126] P. Peng, C. Wang, Z. Shi, V. K. Johns, L. Ma, J. Oyer, A. Copik, R. Igarashi, Y. Liao, Org. Biomol. Chem. 11 (2013) 6671-6674.

[127] U. Hasegawa, A. J. van der Vlies, E. Simeoni, C. Wandrey, J. A. Hubbell, J. Am. Chem. Soc., 132 (2010) 18273-18280.

[128] P. C. Kunz, H. Meyer, J. Barthel, S. Sollazzo, A. M. Schmidt, C. Janiak, Chem. Commun., 49 (2013) 4896-4898.

[129] J. B. Matson, M. J. Webber, V. K. Tamboli, B. Weber, S. I. Stupp, Soft Mater. 8 (2012) 6689-6692.

[130] S. Pai, K. Radacki, U. Schatzschneider, Eur. J. Inorg. Chem. (2014) 2886- 2895.

[131] C. Bischof, T. Joshi, A. Dimri, L. Spiccia, U. Schatzschneider, Inorg. Chem., 52 (2013) 9297-9308.

[132] H. Pfeiffer, T. Sowik, U. Schatzschneider, J. Organomet. Chem., 734 (2013) 17-24. 
[133] C. S. Jackson, S. Schmitt, Q. P. Dou, J. J. Kodanko, Inorg. Chem., 50 (2011) 53365338.

[134] H. Tabe, K. Fujita, S. Abe, M. Tsujimoto, T. Kuchimaru, S. K. Kondoh, M. Takano, S. Kitagawa, T. Ueno, Inorg. Chem. 54 (2015) 215-220.

[135] I. S. Albuquerque, H. F. Jeremias, M. C. Ferreira, D. M. Vinkovic, O. Boutureira, C. C. Romao, G. J. L. Bernardes, Chem. Commun., 51 (2015) 3993-3996.

[136] M. C. Ferreira, I. S. Albuquerque, D. M. Vinkovic, A. C. Coelho, S. M. Carvalho, L. M. Saraiva, C. C. Romao, G. J. L. Bernardes, Angew Chem Int. Ed., 54 (2014) 11721175.

[137] K. Fujita, Y. Tanaka, T. Sho, S. Ozeki, A. Abe, T. Hikage, T. Kuchimaru, S. K. Kondoh, T. Ueno, J. Am. Chem. Soc., 136 (2014) 16902-16908.

[138] F. Zobi, L. Quaroni, G. Santoro, T. Zlateva, O. Blacque, B. Sarafimov, M. C. Schaub, A. Y. Bogdanova, J. Med. Chem., 56 (2013) 6719-6731.

[139] F. Zobi, O. Blacque, R. A. Jacobs, M. C. Schaub, A. Y. Bogdonova, Dalton. Trans. 41 (2012) 370-378. 
[140] A. C. Pena, N. Penacho, L. M. Silva, R. Neres, J. D. Seixas, A. C. Fernandes, C. C.

Romao, M. M. Mota, G. J. L. Bernardes, A. Pamplona, Antimicrob. Agents Chemother. 56 (2012) 1281-1290.

[141] P. Govender, S. Pai, U. Schatzschneider, G. S. Smith, Inorg. Chem., 52 (2013) $5470-5478$.

[142] D. Nguyen, N. N. M. Adnan, S. Oliver, C. Boyer, Macromol. Rapid Commun. (2016) DOI: 10.1002/marc.201500755.

[143] C. Steiger, T. Luhmann, L. Meinel, J. Controlled Release, 189 (2014) 46-53. 


\section{Illustrated Synopsis}

This review focuses on the potential of mesoporous silica nanomaterials as carriers of nitric oxide, carbon monoxide and hydrogen sulfide for site-specific controlled delivery of these gasotransmitters to biological targets.

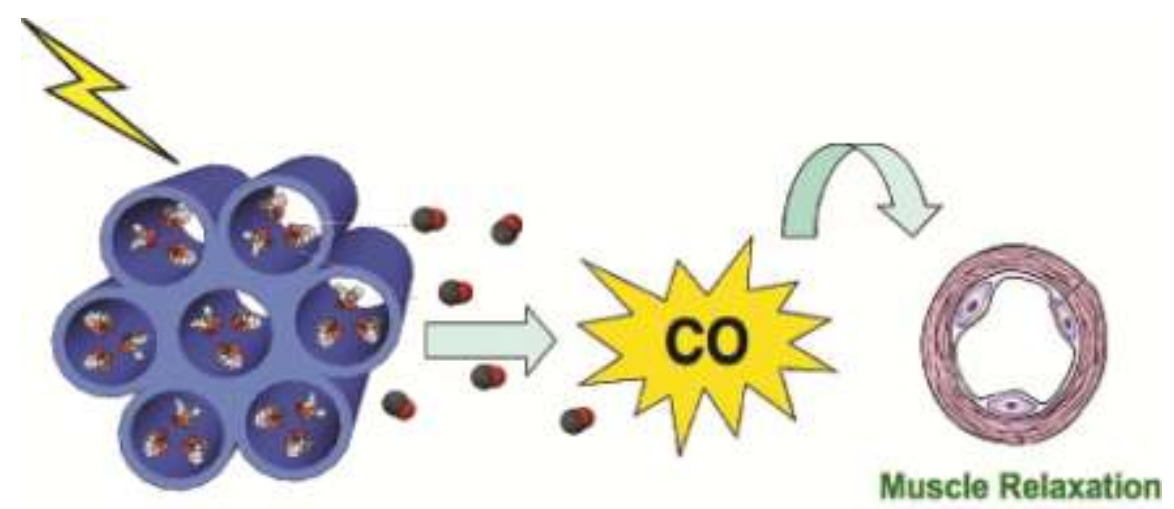

